Pesq. Vet. Bras. 37(12):1526-1530, dezembro 2017

DOI: $10.1590 / \mathrm{S} 0100-736 \mathrm{X} 2017001200027$

\title{
Radiographic measurements related with the cardiac size in young female Bergamasca sheep ${ }^{1}$
}

\author{
Viviam R. Babicsak ${ }^{2 *}$, Lidiane S. Alves ${ }^{2}$, Miriam H. Tsunemi ${ }^{3}$ and Luiz C. Vulcano ${ }^{2}$ \\ ABSTRACT.- Babicsak V.R., Alves L.S., Tsunemi M.H. \& Vulcano L.C. 2017. Radiographic \\ measurements related with the cardiac size in young female Bergamasca sheep. Pes- \\ quisa Veterinária Brasileira 37(12):1526-1530. Departamento de Reprodução Animal e Ra- \\ diologia Veterinária, Faculdade de Medicina Veterinária e Zootecnia, Universidade Estadual \\ Paulista, Campus de Botucatu, Rua Prof. Doutor Walter Mauricio Correa s/n, Botucatu, SP \\ 18618-681, Brazil. E-mail: viviam.babicsak@gmail.com \\ In thoracic radiographic examination, routinely used in cases which cardiac evalua- \\ tion is indicated, quantitative assessment of the heart is a useful role to be used in com- \\ bination with subjective analysis. Numerous studies about objective assessment of the \\ cardiac size have been performed in several species, including sheep; however, there is \\ scarce information regarding cardiac parameters of young Bergamasca sheep. Therefore, \\ the purpose of this study was to determine the average results and suggest the range of \\ expected normal values for parameters related to the heart size of young female Berga- \\ masca sheep by radiographic evaluation. Fifteen healty 8 months-old female Bergamasca \\ sheep (mean weight: $41.13 \pm 4.71 \mathrm{~kg}$ ) were submitted to right lateral recumbency thoracic \\ radiography. The length of the fourth and third to fifth thoracic vertebrae, cardiac height \\ and width, vertebral heart size, cardiophrenic contact, caudal vena cava height, aorta \\ caliber and tracheal angle were measured and the mean results found were, respective- \\ ly: $2.46 \pm 0.11 \mathrm{~cm}(95 \%$ CI $2.41-2.52), 7.53 \pm 0.30 \mathrm{~cm}(95 \%$ CI $7.38-7.68), 13.83 \pm 0.57 \mathrm{~cm}$, \\ (95\% CI 13.54-14.12), 8.99 $\pm 0.37 \mathrm{~cm}(8.80-9.17), 8.99 \pm 0.27$ vertebrae (95\% 8.85-9.13), \\ $4.55 \pm 0.70 \mathrm{~cm}(95 \%$ CI $4.19-4.90), 1.88 \pm 0.19 \mathrm{~cm}(95 \%$ CI $1.79-1.97), 2.05 \pm 0.11 \mathrm{~cm}(95 \%$ \\ CI $2.00-2.11$ ) and $14.36 \pm 2.73^{\circ}$ (95\% CI 12.98-15.75). Cardiac height and width and the \\ sum of these parameters were compared to the length of third to fifth thoracic vertebrae, \\ resulting in the respective mean values: $1.84 \pm 0.08$ (95\% IC 1.80-1.88), $1.20 \pm 0.05$ (1.17- \\ 1.22 ) and $3.04 \pm 0.11$ (95\% IC 2.98-3.09). Ratios of cardiophrenic contact to cardiac hei- \\ ght and caudal vena cava height to length of fourth thoracic vertebra were also evaluated \\ and the mean values obtained were $0.33 \pm 0.05$ (95\% IC $0.30-0.35)$ and $0.76 \pm 0.08(95 \%$ \\ IC $0.72-0.81$ ), respectively. Authors suggest that the values available in this study may be \\ used as reference for normal heart size in young female Bergamasca sheep and as basis \\ for further studies.
}

INDEX TERMS: Radiography, heart, sheep, cardiology, radiology, morphometry.

\footnotetext{
${ }^{1}$ Received on October 11, 2016.

Accepted for publication on April 6, 2017.

${ }^{2}$ Departamento de Reprodução Animal e Radiologia Veterinária, Faculdade de Medicina Veterinária e Zootecnia (FMVZ), Universidade Estadual Paulista (Unesp), Campus de Botucatu, Rua Prof. Doutor Walter Mauricio Correa s/n, Botucatu, SP 18618-681, Brazil. *Corresponding author: viviam.babicsak@gmail.com

${ }^{3}$ Departamento de Bioestatística, Instituto de Biociências, Unesp, Campus de Botucatu, Rua Prof. Doutor Walter Mauricio Correa s/n, Botucatu, SP 18618-681, Brazil.
}

RESUMO.- [Mensurações radiográficas relacionadas às dimensões cardíacas em borregas Bergamácia.] No exame radiográfico torácico, rotineiramente utilizado em casos em que a avaliação cardíaca é indicada, a análise quantitativa do coração é um recurso útil a ser usado em combinação com a avaliação subjetiva. Diversos estudos relacionados à análise objetiva do tamanho cardíaco têm sido realizados em várias espécies, incluindo ovinos; no entanto, há pouca informação sobre os parâmetros cardíacos de ovinos jovens da raça Bergamácia. Dessa for- 
ma, o objetivo deste estudo foi determinar as médias e sugerir o intervalo de valores esperados para os parâmetros relacionados ao tamanho cardíaco de borregas Bergamácia por meio da avaliação radiográfica. Quinze borregas Bergamácia de 8 meses de idade (média de peso: $41,13 \pm 4,71 \mathrm{~kg}$ ) foram submetidas à radiografia torácica em decúbito lateral direito. 0 comprimento do quarto e da terceira a quinta vértebras torácicas, a altura e a largura cardíaca, o tamanho do coração em relação à unidade de vértebra torácica, o contato cardiofrênico, a altura da veia cava caudal, o calibre da aorta e o ângulo traqueal foram mensurados, sendo encontrados os seguintes valores médios, respectivamente: $2,46 \pm 0,11 \mathrm{~cm}(95 \%$ IC 2,412,52), 7,53 $\pm 0,30 \mathrm{~cm}(95 \%$ IC 7,38-7,68), $13,83 \pm 0,57 \mathrm{~cm}$,

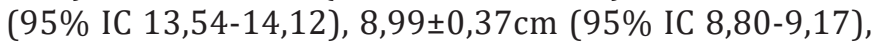
$8,99 \pm 0,27$ vértebras ( $95 \%$ IC $8,85-9,13), 4,55 \pm 0,70 \mathrm{~cm}$ (95\% IC 4,19-4,90), $1,88 \pm 0,19 \mathrm{~cm}(95 \%$ IC $1,79-1,97)$, $2,05 \pm 0,11 \mathrm{~cm}(95 \%$ IC $2,00-2,11)$ e $14,36 \pm 2,73^{\circ}(95 \%$ IC 12,98-15,75). A altura e a largura cardíaca e a soma desses parâmetros foram comparados com o comprimento da terceira a quinta vértebras torácicas, resultan-

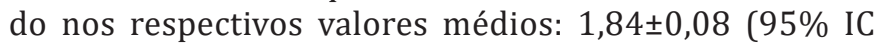
$1,80-1,88), 1,20 \pm 0,05(1,17-1,22)$ e $3,04 \pm 0,11$ (95\% IC $2,98-3,09)$. Também foram avaliadas as relações entre o contato cardiofrênico e a altura cardíaca e entre a altura da veia cava caudal e o comprimento da quarta vértebra torácica, sendo determinados os valores médios de $0,33 \pm 0,05(95 \%$ IC $0,30-0,35)$ e $0,76 \pm 0,08$ (95\% IC 0,72$0,81)$, respectivamente. Os autores sugerem que os valores disponíveis no presente estudo podem ser utilizados como referência na avaliação das dimensões cardíacas de borregas Bergamácia e como base para estudos futuros.

TERMOS DE INDEXAÇÃO: Radiografia, coração, borregas, ovinos, cardiologia, radiologia, morfometria.

\section{INTRODUCTION}

Although echocardiography plays a substantial role in assessment of the heart, thoracic radiography contributes a lot in the evaluation of the cardiovascular system and it is often the first diagnostic imaging technique performed in cases of suspicion of cardiac diseases.

Radiographic abnormalities of the cardiac silhouette, however, are only detected if normal parameters are known and, to this end, abundant studies related to the radiographic assessment of the cardiac size have been performed in several species, including cats (Lord \& Zontine 1977, Litster \& Buchanan 2000a, Litster \& Buchanan 2000b, Ghadiri et al. 2008), dogs (Lehmkuhl et al. 1997, Lamb et al. 2001, Bavegems et al. 2005, Hansson et al. 2005, Marin et al. 2007, Spasojević-Kosić et al. 2007, Kraetschmer et al. 2008), ferrets (Stepien et al. 1999), llamas (Mattoon et al. 2001), psittacines (Straub et al. 2002), cattle (Jilintai et al. 2006), monkeys (Harada et al. 2009), rabbits (Onuma et al. 2010) and alpacas (Nelson et al. 2011).

In young individuals, radiographic evaluation of the cardiac size is challenger, since heart normally appears to be larger in relation to thoracic size in these animals in comparison to its aspect in maturity (Owens \& Biery 1999). The relative variation in heart size in young individuals have motivated investigations related to the normal radiographic anatomy and, in consequence, studies have been conducted in young individuals of some species, including cats (Gaschen et al. 1999), dogs (Sleeper \& Buchanan 2001), cattle (Jilintai et al. 2006), monkeys (Harada et al. 2009), alpacas (Nelson et al. 2011) and goats (Ukaha et al. 2013), in order to provide normal references and, consequently, aid in the diagnosis of cardiac diseases.

In young sheep, there are only a few reports available in the literature related to the radiographic evaluation of the cardiac size, which were conducted in young Santa Ines (Souza et al. 2012) and neonatal Ile de France (Ulian 2015) individuals. Due to the paucity of information, the purpose of this study was to determine the mean results and suggest the range of expected normal values for radiographic parameters related to the cardiac size in young female Bergamasca sheep.

\section{MATERIALS AND METHODS}

Ethics approval was obtained from Ethics Committee on Animal Experimentation of the School of Veterinary Medicine and Animal Science of São Paulo State University (Protocol number $107 / 2013)$, in accordance with the ethical principles adopted by the Brazilian College of Animal Experimentation.

Fifteen healthy 8 months-old female Bergamasca sheep from a herd maintained by the School of Veterinary Medicine and Animal Science of São Paulo State University were radiographed in this study. All animals were considered clinically normal and none presented any alteration during pulmonary and cardiac auscultation. The average weight of the animals of this study was $41.13 \mathrm{~kg}$ and the standard deviation was $4.71 \mathrm{~kg}$.

Right lateral recumbency radiographs were obtained in a digital equipment (Pioneer DR 50kw System, GE Healthcare, Chalfont St Giles, UK) in full inspiration using a focal-film distance of 100 $\mathrm{cm}$ and exposure factors of $4.0 \mathrm{~mA}, 200 \mathrm{mAs}$ and $80-90 \mathrm{kVp}$. In all individuals, the entire thorax (defined by inclusion of the entire lung field, the thoracic spine and sternum) could be included in only one image. The animals were not sedated or anesthetized for this study.

Radiographic images were evaluated using a software program for medical imaging analysis (Clear Canvas, Clear Canvas Inc, Toronto, Canada) by two independent experienced radiologists. All measurements were performed in triplicate by the two observers and then the mean of all values obtained for each variable was calculated.

Length of the third (T3) to fifth (T5) thoracic vertebrae was measured from the mid-point of the cranial endplate of T3 to the mid-point of the caudal endplate of T5. Length of the fourth thoracic vertebra (T4) was also determined by measuring from the mid-point of the cranial endplate to the mid-point of the caudal endplate. Cardiac height (base-to-apex) was measured from the ventral floor of the origin of the mainstem bronchi to the apex of the heart. Cardiac width (cranial-to-caudal) resulted from the measurement of the junction of the ventral margin of the caudal vena cava in caudal border of the heart to the cranial margin of the cardiac silhouette in a perpendicular direction in relation to long axis. The measurement of the heart size using the vertebral scale system described by Buchanan \& Bücheler (1995) was also performed by repositioning the cardiac height and width over 
the thoracic vertebrae beginning at the level of the cranial edge of T4. The vertebral sum of both measures was considered the vertebral heart size value. The measurement of the cardiophrenic contact, determined by the distance from the apex of the heart to the dorsal-most point of intersection of the cardiac silhouette with diaphragm, was also recorded. Caudal vena cava height was measured from its ventral to dorsal limits in the region of greatest diameter, not overlapping the heart or diaphragm and, at the same intercostal space where the caudal vena cava was measured, the caliber of the aorta was determined. Tracheal angle

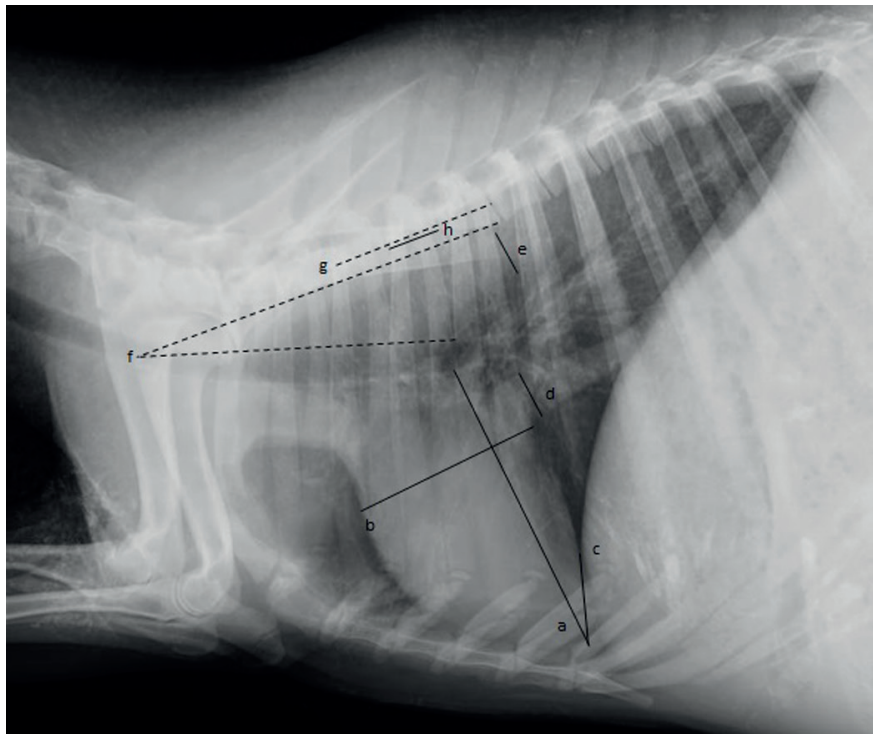

Fig.1. Thoracic radiographic image illustrating the measurement of the cardiac height (a) and width (b). The measurement of the cardiophrenic contact, the distance from the apex of the heart to the dorsal-most point of intersection of the cardiac silhouette with the diaphragm, is also illustrated (c). The measurement of the greatest caliber of the caudal vena cava is demonstrated (d), as well as aorta height (e), measured in the same intercostal space where the caudal vena cava dimension was obtained. Tracheal angle, defined as the angle between the lines drowned along the dorsal border of the trachea and the ventral margin of the cranial thoracic vertebrae, is also illustrated (f). Length of the third to fifth thoracic vertebrae (g) and fourth thoracic vertebra (h) are also shown. was obtained by measuring the angle between the lines drowned along the dorsal border of the trachea and ventral margin of T3 through T5. All measurements performed in this study are illustrated in Figure 1.

To account for differences in size of the individuals, ratios of cardiac height, cardiac width and the sum of cardiac height and width to length of T3 through T5 were calculated, as well as ratios of cardiophrenic contact to cardiac height and caudal vena cava height to length of T4.

Statistical analysis was performed by use of the statistical program SPSS 17.0 (SPSS Inc., Chicago, USA). Mean, standard deviation, range and $95 \%$ confidence interval (CI) about the mean were calculated for all parameters. Correlation coefficients between body weight and some variables (length of T3 through T5, length of T4 and cardiac height) were determined in order to investigate the existence of correlation between body weight and skeletal size. $\mathrm{P}<0.05$ was considered significant. Coefficients of variation of vertebral heart size and ratios of cardiac height to length of T3 through T5, cardiac width to length of T3 through T5 and the sum of cardiac height and width to length of T3 through T5 were calculated as the standard deviation/mean $\times 100$. Mean and $95 \%$ confidence interval about the mean of the coefficients of variation were determined.

\section{RESULTS}

Means, standard deviations, range values and 95\% confidence intervals about the mean of the variables are recorded in Table 1.

Considering correlation coefficients, significant positive linear relations were identified between weight and length of T4 ( $r=0.852, p=0.000)$, weight and length of T3 through T5 ( $\mathrm{r}=0.694, \mathrm{p}=0.000)$ and weight and cardiac height $(r=0.669, p=0.012)$, indicating that body size and weight are related (Fig.2).

Coefficient of variation found for the vertebral heart size was $3.05 \%$ (95\% CI, 2.23 to $4.81 \%$ ), ratio of cardiac height to length of T3 through T5 was 4.09\% (95\% CI, 2.99 to $6.44 \%$ ), ratio of cardiac width to length of T3 through T5 was $3.80 \%$ (95\% CI, 2.78 to $5.98 \%$ ) and ratio of the sum of cardiac height and width to length of T3 through T5 was $3.47 \%$ (95\% CI, 2.54 to $5.47 \%$ ). The analysis showed that the vertebral heart size had the minor coefficient of variation (3.05\%) (Fig.3).

Table 1. Means, standard deviations (SD), range values and $95 \%$ confidence intervals (CIs) of the parameters related to heart and body sizes

\begin{tabular}{lccc}
\hline \multicolumn{1}{c}{ Parameters } & Mean \pm SD & Range & 95\% CIs \\
\hline Weight (kg) & $41.13 \pm 4.71$ & $34.50-49.50$ & $38.75-43.52$ \\
Length of T3 through T5 $(\mathrm{cm})$ & $7.53 \pm 0.30$ & $7.01-8.23$ & $7.38-7.68$ \\
Length of T4 $(\mathrm{cm})$ & $2.46 \pm 0.11$ & $2.30-2.72$ & $2.41-2.52$ \\
Cardiac height $(\mathrm{cm})$ & $13.83 \pm 0.57$ & $12.82-14.51$ & $13.54-14.12$ \\
Cardiac width $(\mathrm{cm})$ & $8.99 \pm 0.37$ & $8.24-9.56$ & $8.80-9.17$ \\
Cardiophrenic contact $(\mathrm{cm})$ & $4.55 \pm 0.70$ & $3.23-5.80$ & $4.19-4.90$ \\
Caudal vena cava height $(\mathrm{cm})$ & $1.88 \pm 0.19$ & $1.58-2.17$ & $1.79-1.97$ \\
Aorta height $(\mathrm{cm})$ & $2.05 \pm 0.11$ & $1.91-2.26$ & $2.00-2.11$ \\
Tracheal angle ${ }^{\circ}$ ) & $14.36 \pm 2.73$ & $9.02-19.33$ & $12.98-15.75$ \\
Vertebral heart scale (vertebrae) & $8.99 \pm 0.27$ & $8.55-9.48$ & $8.85-9.13$ \\
Ratio of cardiac height to length of T3 through T5 & $1.84 \pm 0.08$ & $1.69-1.96$ & $1.80-1.88$ \\
Ratio of cardiac width to length of T3 through T5 & $1.20 \pm 0.05$ & $1.12-1.29$ & $1.17-1.22$ \\
Ratio of cardiac height + width to length of T3 through T5 & $3.04 \pm 0.11$ & $2.83-3.18$ & $2.98-3.09$ \\
Ratio of cardiophrenic contact to cardiac height & $0.33 \pm 0.05$ & $0.23-0.41$ & $0.30-0.35$ \\
Ratio of caudal vena cava height to length of T4 & $0.76 \pm 0.08$ & $0.62-0.88$ & $0.72-0.81$
\end{tabular}



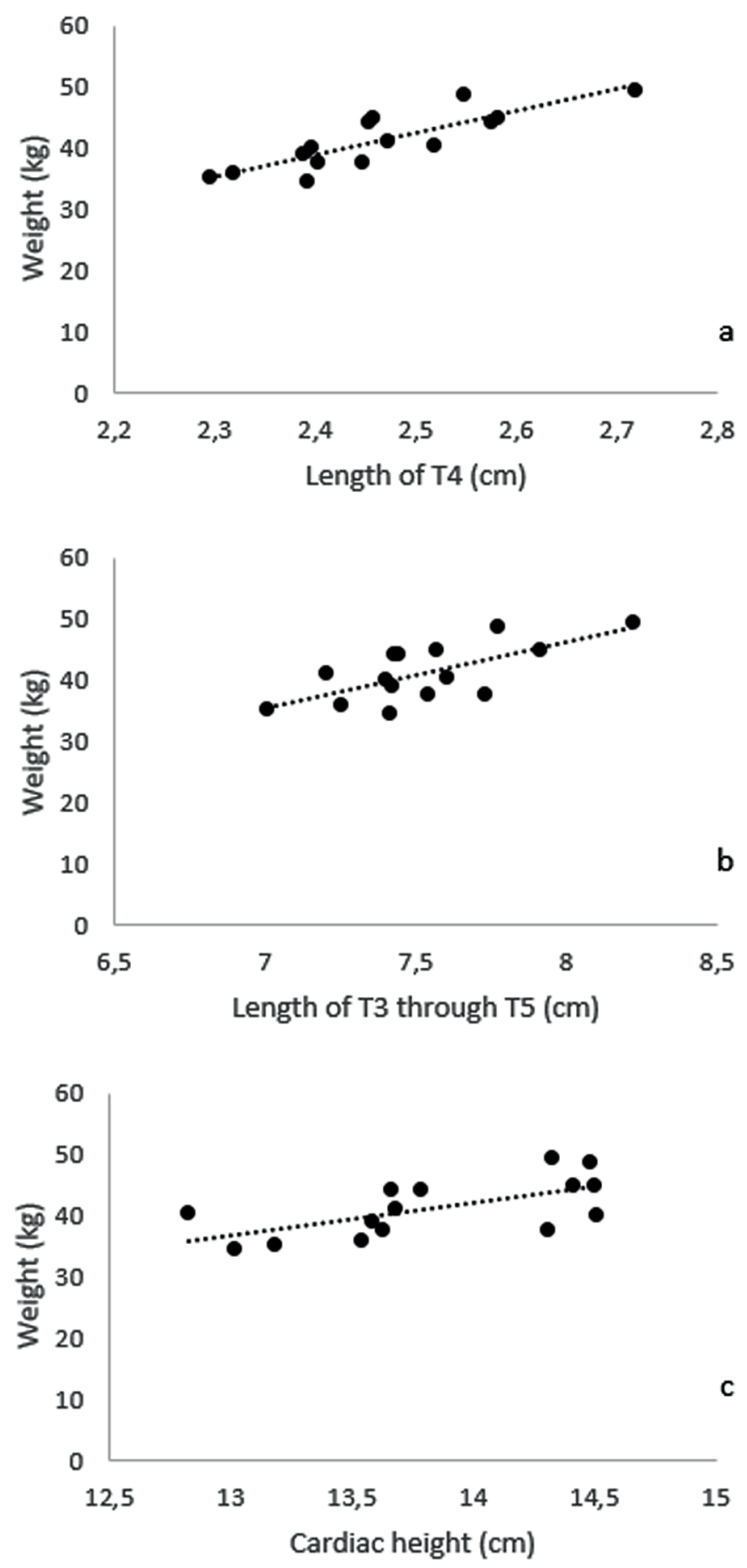

Fig.2. Graphs illustrating positive linear correlations between (a) weight and length of T4 ( $2=0.852, n=15, p<0.000)$, (b) weight and length of T3 through T5 (r2=0.694, n=15, p<0.000), and (c) weight and cardiac height ( $\mathrm{r} 2=0.669, \mathrm{n}=15, \mathrm{p}=0.012)$.

\section{DISCUSSION}

Subjective assessment of the heart is usually performed in radiographic evaluation of the cardiac silhouette, along with objective analysis, which provides important information about cardiac size with little interobserver variation and aids non-experienced radiologists, who often show difficulty in distinguish cardiac abnormalities (Buchanan \& Bücheler 1995, Kittleson \& Kienle 1998). In objective

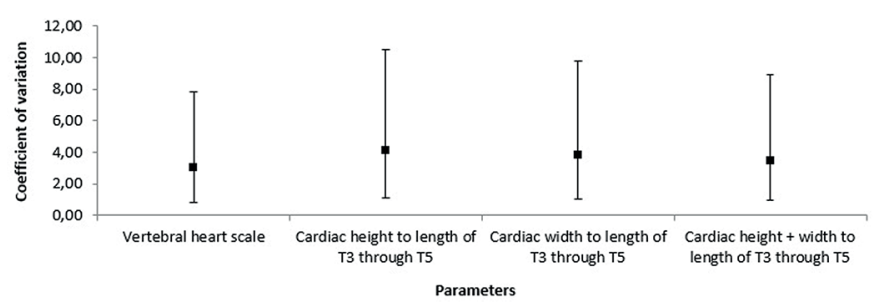

Fig.3. Schematic representation of the coefficient of variation and 95\% confidence intervals (CIs) calculated for the vertebral heart size and ratios of cardiac height to length of T3 through $\mathrm{T} 5$, cardiac width to length of T3 through T5 and the sum of cardiac height and width to length of T3 through T5.

analysis, ratios comparing cardiac measurements to thoracic feature reflective of body size are very useful in cardiac evaluation, as well as vertebral heart size method, since, in contrast to absolute cardiac measurements such as cardiac height and width, they minimize false positive diagnoses of cardiomegaly associated to body size, thoracic conformation and magnification of the radiographic image (Buchanan \& Bücheler 1995, Mattoon et al. 2001).

Stepien et al. (1999) observed that, in ferrets, cardiac ratios appeared to result in lower measurement variation than the modified vertebral heart size method used in their study. On the contrary, in the present study, vertebral heart size showed the lowest coefficient of variation in comparison to the cardiac ratios, such as cardiac height and/or width to length of $\mathrm{T} 3$ through $\mathrm{T} 5$ and, therefore, it may be considered the most reliable parameter for cardiac evaluation in young sheep.

Vertebral heart size mean of young Bergamasca sheep $(8.99 \pm 0.27$ vertebrae) was lower than the average value of $10.36 \pm 0.35$ vertebrae determined for 5-months-old Santa Ines individuals (Souza et al. 2012). The result was also lower than the mean values obtained for neonatal Ile de France sheep, which were $10.07 \pm 0.10,9.97 \pm 0.09$, $9.65 \pm 0.09,9.53 \pm 0.08,9.36 \pm 0.09$ and $9.42 \pm 0.08$ vertebrae in 24 hours and 7, 14, 21, 28 and 35 days of life, respectively (Ulian 2015). This finding may be justified by the utilization of older sheep in our study in comparison to the other ones, since Ulian (2015) found a progressive decrease in vertebral heart size in neonatal Santa Ines sheep during the progression of age. Bergamasca sheep also showed lower vertebral heart size mean than West African Dwarf goats (10.1 \pm 0.01 vertebrae) (Ukaha et al. 2013), which may be explained by the deeper thoracic conformation of the goats in comparison to sheep, since this aspect allows greater development of the cardiac axis, especially height.

Radiographic measurement of the cardiophrenic contact is useful in assessment of the cardiac size, since increased ratios of cardiophrenic contact to cardiac height may indicate cardiomegaly in absence of diseases that leads to hypoventilation of the lung or increased intra-abdominal volume (Mattoon et al. 2001). The ratio of cardiophrenic contact to cardiac height calculated for sheep $(0.33 \pm 0.05)$ was lower than the value found for alpaca crias $(0.39 \pm 0.10)$ (Nelson et al. 2011), which may be explained by the existence of a lower cardiophrenic contact and/or a higher cardiac height in sheep in comparison to alpacas. Greater 
thoracic and/or lower intra-abdominal volumes in sheep may also justify the differences in cardiophrenic ratios since these conditions may interfere in cardiophrenic contact measurement (Mattoon et al. 2001).

Ratio of caudal vena cava diameter to length of T4 is also a valuable parameter in radiographic evaluation of the heart, since elevated values are suggestive of right-sided congestive heart (Lehmkuhl et al. 1997, Jilintai et al. 2006). The ratio of caudal vena cava height to length of T4 found for sheep in our study $(0.76 \pm 0.08)$ was greater than the value obtained for young cows $(0.41 \pm 0.06)$ (Jilintai et al. 2006) and a fact that may have contributed to this variation was the use of the maximum diameter of the caudal vena cava height in the ratio of sheep and its average size in the ratio of the cattle.

Tracheal angle measurement is an indirect parameter useful in quantitative radiographic evaluation of the cardiac size too, since a reduced tracheal angle indicates a dorsal positioning of the trachea, a radiographic sign usually evident in cardiomegaly (Mattoon et al. 2001). The similarity found between the tracheal angle of young sheep $\left(14.72 \pm 3.08^{\circ}\right)$ and alpaca crias $\left(14.24 \pm 3.57^{\circ}\right)$ (Nelson et al. 2011) may be justified by the resemblance of the thoracic conformation exhibited by these two species.

As conclusion, authors suggest that the values found in this study may be used as reference for heart size in radiographic evaluation of young female Bergamasca sheep and as basis for further investigations in these animals. Future researches using a greater number of animals, as well as male individuals, are need in order to determine additional information related to normal radiographic evaluation of the heart size in this specie.

Individual variability and physiologic factors such as cardiac cycle phase, circulating blood volume, total body fluid, and intra-thoracic and intra-abdominal pressure may have interfered in the measurements and ratios calculated in this study. Phase of respiration may have also affected the results despite the efforts to perform peak inspiratory radiographs.

\section{REFERENCES}

Bavegems V., Van Caelenberg A., Duchateau L., Sys S.U., Van Bree H. \& De Rick A. 2005. Vertebral heart size ranges specific for whippets. Vet. Radiol. Ultrasound 46:400-403.

Buchanan J.W. \& Bucheler J. 1995. Vertebral scale system to measure canine heart size in radiographs. J. Am. Vet. Med. Assoc. 206:194-199.

Gaschen L., Lang J., Lin S., Adé-Damilano M., Busato A., Lombard C.W. \& Gaschen F.P. 1999. Cardiomyopathy in dystrophin-deficient hypertrophic feline muscular dystrophy. J. Vet. Intern. Med. 13:346-356.

Ghadiri A., Avizeh R., Rasekh A. \& Yadegari A. 2008. Radiographic measurement of vertebral heart size in healthy stray cats. J. Feline Med. Surg. 10:61-65.

Hansson K., Haggstrom J., Kvart C. \& Lord P. 2005. Interobserver variability of vertebral heart size measurement in dogs with normal and enlarged hearts. Vet. Radiol. Ultrasound 46:122-130.
Harada M., Koie H., Iwaki S., Sato T., Kanayama K., Taira M. \& Sakai T. 2009. Establishment of vertebral heart scale in the growth period of the Japanese macaque (Macaca fuscata). J. Vet. Med. Sci. 72:503-505.

Jilintai, Hashiyama S., Gonda Y., Ishikawa H., Sato M. \& Miyahara K. 2006. Radiographic evaluation of caudal vena cava size as a useful parameter for the diagnosis of heart disease in dairy cattle. J. Vet. Med. Sci. 68:995998.

Kittleson M.D. \& Kienle R.D. 1998. Small Animal Cardiovascular Medicine. Mosby, St Louis. 603p.

Kraetschmer S., Ludwig K., Meneses F., Nolte I. \& Simon D. 2008. Vertebral heart scale in the beagle dog. J. Small Anim. Pract. 49:240-243.

Lamb C.R., Wikeley H., Boswood A. \& Pfeiffer D.U. 2001. Use of breed specific ranges for the vertebral heart scale as an aid to the radiographic diagnosis in dogs. Vet. Rec. 148:707-711.

Lehmkuhl L.B., Bonagura J.D., Biller D.S. \& Hartman W.M. 1997. Radiographic evaluation of caudal vena cava size in dogs. Vet. Radiol. Ultrasound 38:94-100.

Litster A.L. \& Buchanan J.W. 2000a. Radiographic and echocardiographic measurement of the heart in obese cats. Vet. Radiol. Ultrasound 41:320325.

Litster A.L. \& Buchanan J.W. 2000b. Vertebral scale system to measure heart size in radiographs of cats. J. Am. Vet. Med. Assoc. 216:210-214.

Lord P.F. \& Zontine W.J. 1977. Radiologic examination of the feline cardio-vascular system. Vet. Clin. N. Am. 7:291-308.

Marin L.M., Brown J., McBrien C., Baumwart R., Samii V.F. \& Couto C.G. 2007. Vertebral heart size in retired racing Greyhounds. Vet. Radiol. Ultrasound 48:332-334.

Mattoon J.S., Gerros T.C. \& Brimacombe M. 2001. Thoracic radiographic appearance in the normal llama. Vet. Radiol. Ultrasound 42:28-37.

Nelson N.C., Mattoon J.S. \& Anderson D.E. 2011. Radiographic appearance of the thorax of clinically normal alpaca crias. Am. J. Vet. Res. 72:14391448.

Onuma M., Ono S., Ishida T., Shibuya H. \& Sato T. 2010. Radiographic measurement of cardiac size in 27 rabbits. J. Vet. Med. Sci. 72:529-531.

Owens J.M. \& Biery D.N. 1999. Radiographic interpretation for the small animal clinician. 2nd ed. Williams and Wilkins, Baltimore. 308p.

Sleeper M.M. \& Buchanan J.W. 2001. Vertebral scale system to measure heart size in growing puppies. J. Am. Vet. Med. Assoc. 219:57-59.

Souza P.M., Rodello L., Inamassu L.R., Monteiro C.T., Babicsak V.R., Machado V.M.V. \& Bicudo S.D. 2012. Radiographic evaluation of the cardiac silhouette by the method of measurement VHS (vertebral heart size) in Santa Ines Boregas clinically normal. XXVII World Buiatrics Congress, XXVII World Buiatrics Congress, Lisboa. p.155.

Spasojević-Kosić L., Krstić N. \& Trailović R.D. 2007. Comparison of three methods of measuring vertebral heart size in German Shepherd dogs. Acta Vet. 57:133-141.

Stepien R.L., Benson K.G. \& Forrest L.J. 1999. Radiographic measurement of cardiac size in normal ferrets. Vet. Radiol. Ultrasound 40:606-610.

Straub J., Pees M. \& Krautwald-Junghanns M.E. 2002. Measurement of the cardiac silhouette in psittacines. J. Am. Vet. Med. Assoc. 221:76-79.

Ukaha R.O., Kene R.O.C. \& Gbonko O.E. 2013. Vertebral scale system to measure heart size in thoracic radiographs of West African Dwarf goats. Nig. Vet. J. 34:912-916.

Ulian C.M.V. 2015. Avaliação do desenvolvimento cardíaco neonatal em cordeiros. Tese de Doutorado. Available on <http://repositorio.unesp.br/bitstream/handle/11449/140231/000865898. pdf?sequence=1\&isAllowed=> Assessed on Oct. 8, 2016. 